\title{
Modern hydrological status of the estuary of Ili River
}

\author{
Zhakupbay Dostay $\cdot$ Sayat Alimkulov \\ Aisulu Tursunova $\cdot$ Akhan Myrzakhmetov
}

Received: 23 January 2012/Accepted: 15 February 2012/Published online: 3 March 2012

(C) The Author(s) 2012. This article is published with open access at Springerlink.com

\begin{abstract}
The study addresses the problems and the history of formation and functioning of one of the largest intracontinental estuaries in Kazakhstan-the Ili River waterway. Being a natural regulator of the ecological status of the region, the estuary of Ili River also influences the water regime of Lake Balkhash. This work studied the current state of hydrographic and hydrological networks in a selected area and the distribution of water flow entering the estuary through the various ducts. Using a water balance method, this study calculated the loss of water in the delta, estimated runoff to the peak of delta and the inflow of river water into Lake Balkhash for two periods: the natural-conditioned and disturbed. As a result of the work performed, it was possible to trace the dynamics of hydraulic parameters for a multiyear period.
\end{abstract}

Keywords Estuary $\cdot$ River delta $\cdot$ Ecosystem .

River basin - River flow - Water resources - Channel .

Waterway - Lake · Hydrological regime - Water volume Peak of delta . Flow losses . Water line

\section{Introduction}

Lake Balkhash, a large water body of Kazakhstan, is of great ecological, economic and social significance. Increase in water problems in the basin of Lake Balkhash, associated with extensive development of the water sectors for the economy, leads to disruption of the functioning sustainable, natural and economic systems of the region.

Z. Dostay $\cdot$ S. Alimkulov

A. Tursunova $\cdot$ A. Myrzakhmetov $(\bowtie)$

Institute of Geography, Almaty, Kazakhstan

e-mail: ahan_myrzahmetov@mail.ru
Lake Balkhash together with the delta of the Ili River is a major water user in a natural basin and, in turn, has a tremendous impact on the system. Proceeding from this, the results of studies of the condition of the Ile-Balkhash delta-lake systems as a determinant of the functioning of natural and economic systems of the region as a whole must be considered when developing schemes for water distribution of the Ili River between Kazakhstan and China.

\section{Current status of the estuary of the Ili River}

The main artery feeding Lake Balkhash is River Ile, which accounts for $80 \%$ of the runoff of all rivers flowing into Lake Balkhash.

At the confluence into Lake Balkhash, River Ile forms a vast delta area of about $8 \mathrm{~km}^{2}$, which is the only preserved delta in Kazakhstan. The delta is hydraulically connected to the lake and serves as a natural regulator for the maintenance of ecological balance in the ecosystem, supplying part of water supplies to the lake in years of drought. It is the habitat of wild animals and birds, as well as the forage for livestock.

The estuary of the Ili River begins (Fig. 1) near the village of the sixth fishing point where the river divides into three arms: eastern-Zhideliyskiy, central-Ileyskiy and western-Toparskiy. Its eastern border runs through the sands of the ancient delta of Saryesik Atyrau; in the south, a huge area of hilly ridged sand, bearing the common name of Taukum, stretches, while the northwest of the modern delta is washed by Lake Balkhash.

The river network of the Ile delta is represented by the branches and channels of the same river. Hydrography of the Ile delta is characterized by a complex system of waterways, floodplains and lakes between the dunes. 
Fig. 1 Study region according to the data by KA MODIS (July 2010)

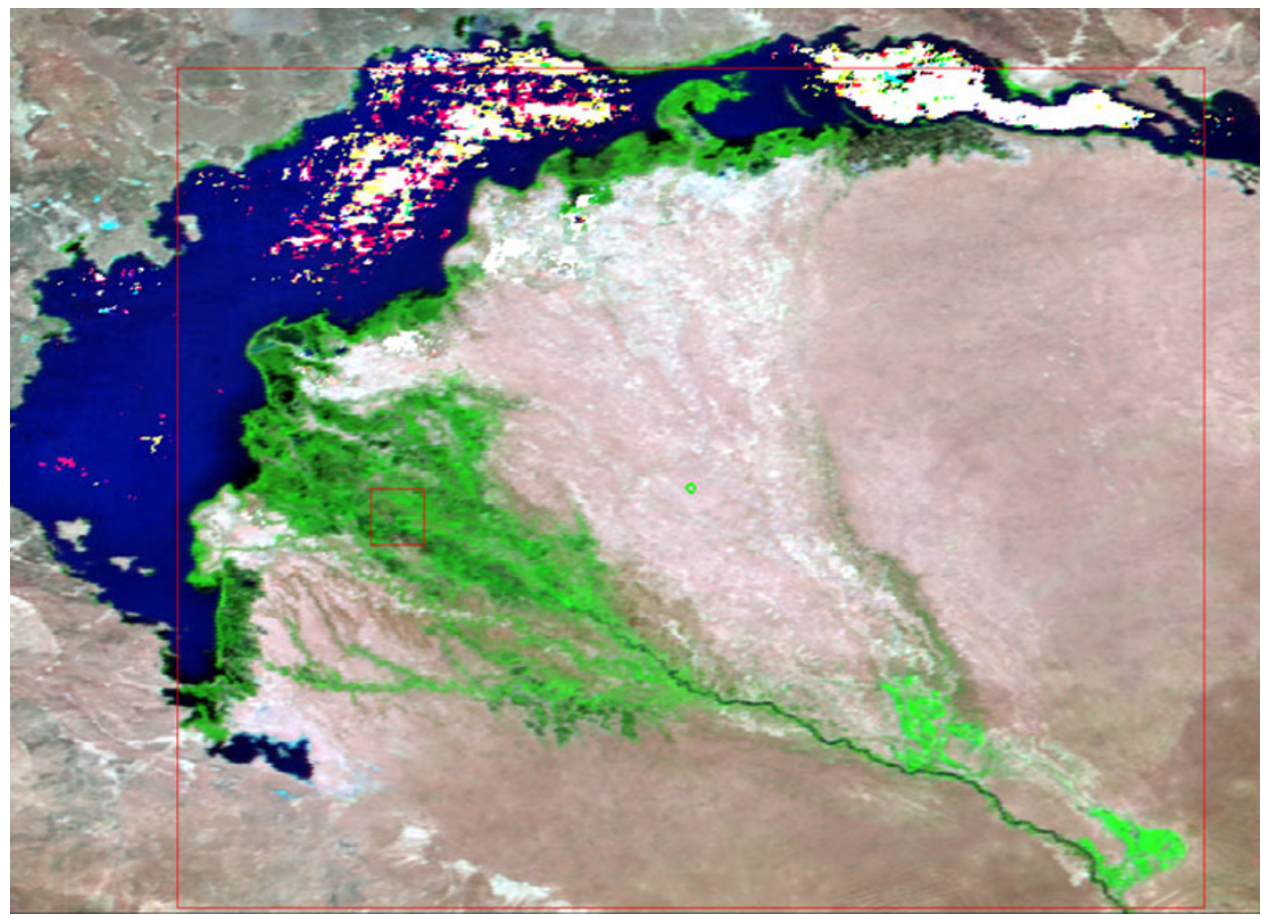

The morphological and hydrographic features in the Ili River delta system comprise three separate streams: Toparskaya, Ileyskaya and Zhidelinskaya.

The Toparskaya system occupies the left bank of the estuary. The starting point of this system consists of the channels Topar I and Topar II, extending from Ile in the sixth fishing point. Currently, the watercourse feeding the Toparskaya system is known as Suminka. Runoff down the Toparskaya system can be observed only at high stands of level of River Ile; therefore, the passing of the water into the system during the last few years is supported by periodic in-depth source of the Suminka duct.

The Ileyskaya system is located in the central part of the delta. It is represented by a transit winding Ile branch, which, at the confluence of Lake Balkhash, forms a small deltaic branching. In the past, the branch was the main watercourse of the Ile delta. As its riverbed sediment system has been filling, it has turned into a minor stream of the delta, to which only $4 \%$ of the runoff is attributed.

The Zhideliyskaya system occupies the right bank of the river delta and is the right side system. It was formed relatively recently, in 1907-1908. In the early 1940s, the water content of the system was much more than the water content of the Ile branch. At present, the bulk Ile runoff$90 \%$ - passes through Zhideliyskaya system. It has a very complicated hydrography; water spreads over the countless channels, lakes and spills.

Ile runoff flows directly into Lake Balkhash through six streams: Ile, Baimenov, Balakashkan, Eer, Shubarkunan and Naryn (Report of scientific research 1989; Dostay 2009).

\section{Hydrological study}

Over the years, hydrological observations in the Ile delta have been performed at 16 network of gauging stations and the Institute of Geography KAZHYDROMET (Fig. 2). At present, systematic observations of the flow regime of the main duct are made at the top of the deltas in three hydrological stations "KazHydroMet" RSE (Table 1):

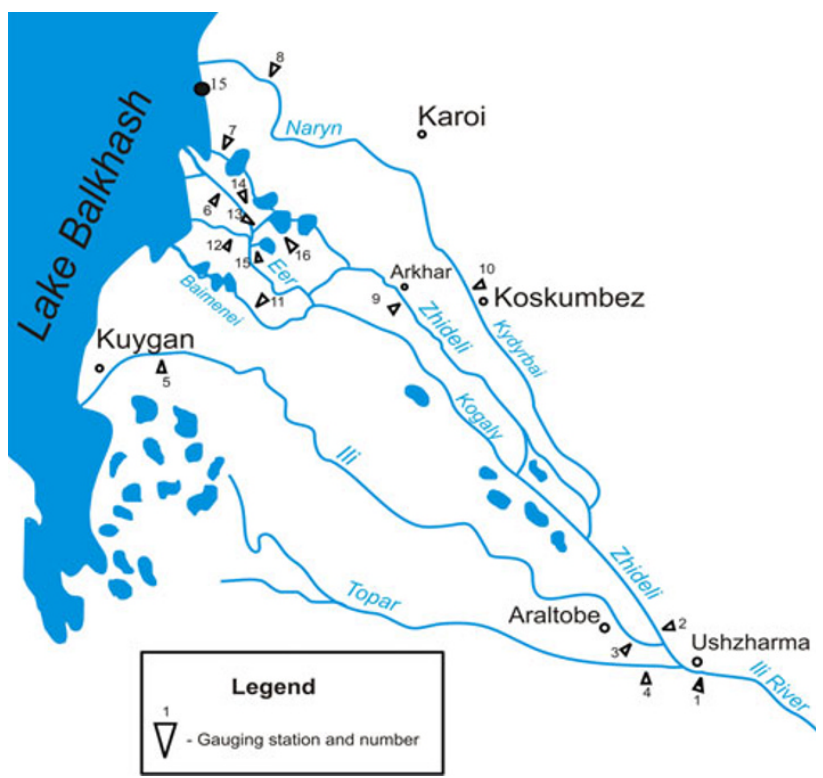

Fig. 2 Schematic positioning of gauging stations 
Table 1 Information on the observation gauging stations

\begin{tabular}{llll}
\hline No. & Gauging station of "Kazhydromet" & No. & Gauging station of "Institute of Geography" \\
\hline 1 & River Ile-Ushzharma village & 9 & Zhideli branch-Arkhar townsite \\
2 & Zhideli branch-16 km lower than the source & 10 & Kadyrbay duct-Koskumbez townsite \\
3 & Ile branch-1 km lower than the Zhideli branch & 11 & Baymeney duct-Baymenej townsite \\
4 & Suminka-6 km lower than the source & 12 & Balakashkan duct \\
5 & Ile branch-Zhideli aul & 13 & Assaubay duct \\
6 & Zhideli branch, Eer duct-2.5 km from the source & 14 & Sologubka duct-mouth \\
7 & Zhideli branch, Shubarkunan branch-1.5 km & 15 & Kustastoe duct-source \\
8 & from the mouth & 16 & Lake Assaubay-Bugor \\
\hline
\end{tabular}

River Ile-Ushzharma and Zhideli branches-16 km below the source; the Ile branch-1 km below the branch Zhideli; and at the mouth of the Zhideli branch. Eer is $2.5 \mathrm{~km}$ upstream from the mouth and branches. These posts mostly cover the flow regime at the inlet and outlet of the delta (Report of scientific research 1991; Surface water resources of Soviet Union 1967, 1970, 1967, 1980; The hydrological yearbooks 1994-2009; State Water Cadastre Republic of Kazakhstan 2001). Also, the Institute of Geography in the 1980s organized hydrometric observations at eight points, including seven in streams and a tide gauge on the Lake Asaubay.

\section{Runoff at the peak of delta}

In connection with the development of economic activities in the Ile basin (flow regulation, development of irrigated agriculture), recently there is a noticeable change in the condition of the surface of the delta that shows signs of gradual drying. The dynamics of the surface of the delta was studied to assess changes in runoff losses as a result of its transformation under the influence of economic activity.

Significant changes in the water regime of the Ile delta were observed from 1970 to 1985. After commissioning Kapshagai HES, water inflow to the delta was said to be reduced, due to partly matured low water, but mostly the big exceptions to drain it and fill losses through evaporation. As a result, the lake level from 1970 to 1987 decreased by $2.3 \mathrm{~m}$, and the surface runoff was reduced to $12.2 \mathrm{~km}^{3}$. That is, Kapshagai Reservoir, on the one hand, created favorable conditions for more rational use of water resources; on the other hand, it led to the emergence of a number of adverse effects in the lower reaches of the Ile (Report of scientific research 1990).

The loss of runoff from the land occurs by evaporation from the many lakes, floods, creeks and transpiration from extensive reed arrays. The various losses depend largely on the degree of hydration of the delta, which in turn is determined by the conductivity of the river (Report of scientific research 2010).

To determine the flow at the apex of the Ile delta, observations of Ile runoff in Kapshagay and Ushzharma have been considered, as well as the total flow of all branches formed in the top of the modern delta (Ile, Zhideli and Suminka).

Analysis of the materials from the Ile runoff at Kapshagay showed that the alignment of data on this cannot be taken because of significant water abstraction for irrigation in the lower reaches of the river.

According to studies (Report of scientific research 1990), the runoff gauging River Ile-Ushzharma was due to lack of reliability (many arms in the range of fasting, lack of level observations in connection with the special conditions of operation of the Kapshagai hydropower, river flows at this location for three beds, and the post being located in one of these channels and subject to continuous erosion) and other reasons also could not be used to estimate the flow of river water to the top of the deltas. Therefore, in determining the flow at the top of the deltas, data from the 1970-2009 years were used in the sources of the total stock of these three branches.

To estimate the statistical parameters of the natural flow entering the top of the deltas, rows from the undisturbed regime need to be selected. Pure natural mode of existing hydrometric observation period is not as irrigation in the Ile basin has existed since before the revolution.

Therefore, we can only speak conditionally of the natural period, when the effect of irrigation was negligible within the accuracy of estimates of water flow, i.e., at no more than 5\% (Report of scientific research 1990).

Conventionally, the natural period may be taken to be from 1930 to 1969 , i.e., to start filling the reservoir Kapshagai. After the construction of the dam, the Kapshagai water inflow to the delta was reduced. The average annual cost of water of different supply flow at the top of the Ile delta presented in Table 2. 
Table 2 Average annual water consumption $\left(\mathrm{m}^{3} / \mathrm{s}\right)$ of various supply flows to the peak of the Ile delta

\begin{tabular}{llllllllll}
\hline Period & $Q$ & $\mathrm{Cv}$ & \multicolumn{7}{c}{ Exceedance probability $(\%)$} \\
\cline { 4 - 10 } & & & 5 & 10 & 25 & 50 & 75 & 90 & 95 \\
\hline $1930-1969$ & 472 & 0.12 & 569 & 546 & 509 & 470 & 432 & 401 & 384 \\
$1970-2009$ & 444 & 0.23 & 721 & 622 & 497 & 400 & 348 & 325 & 318 \\
\hline
\end{tabular}

\section{The distribution of water flow to the branches of the estuary}

The distribution of water flow across the Ile delta has a complex and time-varying nature because active channel processes constantly occur in its drainage network.

The distribution of water flow in the Ile delta in the first place depends on the culvert capacity, which in turn is determined by the stage of its development. The system of hoses and Topar Ile is withering away, especially in recent years in which the process of silting has intensified their origins. To maintain the flow of water into these branches, deepening and clearing of their origins are periodically done.

Very significant impact on the flow distribution in the delta is on economic activity: the overlap of the waterways, excavation of channels, deepening and clearing of channels, etc. (Report of scientific research 1990, 2010).

In the past, the delta had repeated movement of bulk flow from one duct to another. According to LS Berg, in 1903, the most abounding was Topar; in 1941, according to GR Yunusov, the stock split differently: Topar, $18 \%$ or $42 \%$, and Zhideli, $40 \%$ of the total current to the delta. In 1953, Zhideli already held $88 \%$ of the runoff. By the time the construction of hydroelectric Kapshagai had started, primary Ile runoff went through the ducts of Zhideli and Kogaly.

According to Sosedov (1958), the redistribution of runoff total area of the spill in the delta had not changed significantly. Kudrin (1977) indicates that the processes in the Ile delta have direct contact with the lake level. The position of influencing the state of the delta, due to the amount of annual increment from the beginning of the cycle of inter- or multi-year, which accounts for the inertia of the processes occurring in the delta. Accumulating effect of the Ile delta is not constant: it is more in wet than in dry years. Zhirkevich (1972) noted that the main difficulty in studying the water balance of Lake Balkhash is in determining the surface inflow to the lake due to insufficient study of loss of flow in the delta. Their calculations are complicated by the difficulty in obtaining not only reliable data, but also robust cartographic data that reflect the different stages of development of the delta, different distribution of land within its boundaries in different years and water availability.
Flow distribution in the main branch at the top of the deltas of the reservoir after the construction of Kapshagai virtually unchanged. According to a study (Report of scientific research 1990) of the branches, Zhideli 90.2\%, River Ile $5.6 \%$ and Suminka $4.2 \%$ constitute the runoff at the top of the deltas, and according to our calculations, about $92,4.2$ and $4.3 \%$, respectively. The resulting $2 \%$ difference can be explained by the fact that the settlement period is taken up in 1989, while we estimated in a number of extended periods until 2009 the main artery of the aquifer duct Kogaly relating to the Zhidelinskoy system to which up to $70 \%$ River Ile run off.

Regulation of Ile-Kapshagai reservoir runoff led to significant changes in intra-annual distribution. Winter water flow increased almost by $1.5-2.0$, and the flow in the summer months decreased 2.0-2.5 times.

The delta is constantly undergoing complex processes of redistribution of flow between streams, depending on the natural and anthropogenic factors.

For example, in recent years, one of the powerful streams of the delta-hand-Zhideli-gradually silted up and started in 1985, the maximum cost in the range of Argaly town site did not exceed $25-30 \mathrm{~m}^{3} / \mathrm{s}$ (Report of scientific research 1990).

Of the total flow entering the Lake Balkhash from the results of studies (Kudrin 1977), the share of R\&D, etc. is by $61 \%, 5 \%$ Ile, Shubarkunan $20 \%$, the rest of the stock to the amount of $14 \%$ did so on the Naryn Balakashkan, Karaozek and Baimenov.

In 1987, on the recommendation of the Institute of Geography, Academy of Sciences of the Kazakh SSR (Tursunov), dredging was carried out in the source arm in the area $25 \mathrm{~km}$ below the branches of Kogaly, etc. As a result, the capacity has increased in the Zhideli branch, which transports $25 \%$ of the runoff entering the system of Zhidelinskuyu branches (Report of Scientific Research 1990).

As a result of dredging, there has been a marginal change in the distribution in the runoff branches. For example, for the years 1987-2009, Lake Balkhash received $55 \%$ from Eer, $3.3 \%$ from Ile, $17.2 \%$ from Shubarkunan, 4.2\% from Naryn, $9.4 \%$ from Baimenov and $2.8 \%$ from Balakashkan of the total runoff (Table 3).

Research on materials (Report of scientific research 1990) shows increase in the spending of water from Zhideli accompanied by increased erosion-the deepening of watercourses and river bed shows that the average depth of the channel from 1986 to 1988 increased by $1.3 \mathrm{~m}$. The same processes occurred in the channel Kadyrbai.

Recently, activation of the Parshinskaya duct that emerges from the duct and empties into the Kogaly Zhideli sleeve has also been observed. According to KAZGIPROVODKHOZ 1983, the channel passed Parshinskaya 
Table 3 Distribution of Ile River delta runoff on branches

\begin{tabular}{|c|c|c|c|c|c|c|}
\hline \multirow{2}{*}{$\begin{array}{l}\text { Period } \\
\text { Gauging stations }\end{array}$} & \multicolumn{2}{|c|}{ 1970-2009 } & \multicolumn{2}{|c|}{ 1970-1986 } & \multicolumn{2}{|c|}{$1987-2009$} \\
\hline & $Q\left(\mathrm{~m}^{3} / \mathrm{s}\right)$ & $\begin{array}{l}\% \text { from the runoff } \\
\text { at the delta apex }\end{array}$ & $Q\left(\mathrm{~m}^{3} / \mathrm{s}\right)$ & $\begin{array}{l}\% \text { from the runoff } \\
\text { at the delta apex }\end{array}$ & $Q\left(\mathrm{~m}^{3} / \mathrm{s}\right)$ & $\begin{array}{l}\% \text { from the runoff } \\
\text { at the delta apex }\end{array}$ \\
\hline 2. Zhideli branch-16 km & 407 & 91.7 & 331 & 90.7 & 463 & 92.1 \\
\hline 3. River Ile-1 km lower than Zhideli branch & 18.7 & 4.21 & 19.9 & 5.40 & 17.8 & 3.52 \\
\hline 4. Suminka duct & 18.9 & 4.26 & 14.2 & 3.92 & 22.3 & 4.42 \\
\hline 5. River Ile—Zhideli & 14.4 & 3.20 & 16.1 & 4.40 & 13.3 & 3.3 \\
\hline 6. Eer duct & 204 & 45.9 & 181 & 49.7 & 220 & 55.0 \\
\hline 7. Shubarkunan duct & 53.1 & 12.0 & 31.6 & 8.67 & 68.9 & 17.2 \\
\hline 8. Naryn duct & & & & & 16.6 & 4.2 \\
\hline 11. Baimeney duct—fishing point & & & & & 37.6 & 9.4 \\
\hline 12. Balakashkan duct & & & & & 11.3 & 2.8 \\
\hline
\end{tabular}

$3.0-8.0 \mathrm{~m}^{3} / \mathrm{s}$, but since 1987 spending of water it had increased to $20 \mathrm{~m}^{3} / \mathrm{s}$. The process of increasing water content at Parshinskaya has been undertaken so that when the source of the siltation is Zhideli (at this point ZhideliKogaly), which is observed at the present time, the water content of the latter in the near future will not undergo significant changes (Report of scientific research 1990).

Nevertheless, the implementation of measures for the redistribution of flow between Kogaly and Zhideli toward a significant increase in water flow was achieved. It should be noted that the terminal section of hands. Zhideli is the largest lake system Asaubay requiring irrigation and importance to fisheries. On the other hand, such redistribution would prevent unwanted channel deformations in others such as Kogaly and overflow of its waters into undrained depressions. In 1987-1988, water from Kogaly started flooding the adjacent slides, including some locations.

\section{Water losses in the delta}

An assessment of flow losses in the Ile delta is of particular importance in the economic activity of the Ile-Balkhash pool. Over the years, this issue has been addressed by many scientists from various research institutes and industrial organizations, who conducted field studies of this area (Uvarov 1997; Abdrasilov 1994; Geology of the USSR 1971; Report of scientific research 1991; Tursunov et al. 1985).

River runoff silt coming into the delta spreads over numerous streams, lakes and spills. As a result, part of it does not reach Lake Balkhash, and is lost by evaporation from water surface and by evaporation and transpiration by plants from moist areas. Some of the water is used to fill depressions between channels and groundwater recharge.
The study was carried out by assessing the loss of channel flow in the delta that is the difference of the flow of surface water to the top of the deltas and the outflow from the delta into the Lake Balkhash.

Channel losses are a source of power to the delta. During a high-water year, the greater the delta flooding, the more are the runoff losses.

The Institute of Geography in 1991 on the basis of observational Lengidepa, Kazakh Branch of the Institute of the Hydrometeorological Service of the Kazakh SSR and HYDROPROJECT performed the non-regulated assessment of water losses in the Ile delta, at intervals during the years 1953-1969 (Report of scientific research 1991).

Prior to the construction of the Kapshagai reservoir in 1953-1969, mean annual flow losses in the Ile delta according to (Report of scientific research 1991) was $3.2 \mathrm{~km}^{3}$ or $21 \%$ of the incoming flow to the top of the deltas. The greatest losses occurred in 1959 and equaled $6.1 \mathrm{~km}^{3}$ or $30 \%$ of the runoff at the top of the deltas, and the lowest losses occurred in 1957 and accordingly were $1.2 \mathrm{~km}^{3}$ or $11 \%$ of the runoff at the top of the deltas.

Mean flow losses in the Ile delta in these studies were calculated for the period 1970-2009 and it was $3.6 \mathrm{~km}^{3}$ ( $26 \%$ of the inflow to the top of the deltas). After the construction of the Kapshagai hydroelectric plant, loss of flow in the apex of the delta increased by $0.4 \mathrm{~km}^{3}$. It should be noted that compared to the years 1970-2009, stock in the top of the delta, as well as the incoming flow into the Lake Balkhash for the years 1953-1969 was greater by $1 \mathrm{~km}^{3}$ (Table 4).

The analysis showed that flow in 1970 for the Ile delta was abnormal: the outflow of water in the Lake Balkhash slightly higher than the inflow to the delta. This is explained by the fact that 1969 was an abundant year, and large amounts of water had accumulated in the delta. In 1970 , the first year of the initial and intense filling of the 
Table 4 Loss of flow in the Ile delta

\begin{tabular}{|c|c|c|c|c|c|c|c|}
\hline \multirow[t]{2}{*}{ Period } & \multicolumn{2}{|c|}{$\begin{array}{l}\text { Runoff at the } \\
\text { delta apex }\end{array}$} & \multicolumn{2}{|c|}{$\begin{array}{l}\text { Runoff entering } \\
\text { Lake Balkhash }\end{array}$} & \multicolumn{2}{|c|}{$\begin{array}{l}\text { Losses in } \\
\text { delta }\end{array}$} & \multirow[t]{2}{*}{$\%$} \\
\hline & $\mathrm{m}^{3} / \mathrm{s}$ & $\mathrm{km}^{3}$ & $\mathrm{~m}^{3} / \mathrm{s}$ & $\mathrm{km}^{3}$ & $\mathrm{~m}^{3} / \mathrm{s}$ & $\mathrm{km}^{3}$ & \\
\hline 1953-1969 (Report of scientific research 1990) & 477 & 16.5 & 377 & 11.9 & 101 & 3.18 & 20.4 \\
\hline 1970-2009 & 444 & 14.0 & 330 & 10.4 & 114 & 3.63 & 26.0 \\
\hline
\end{tabular}

Fig. 3 Change in runoff losses in the delta of the Ili River

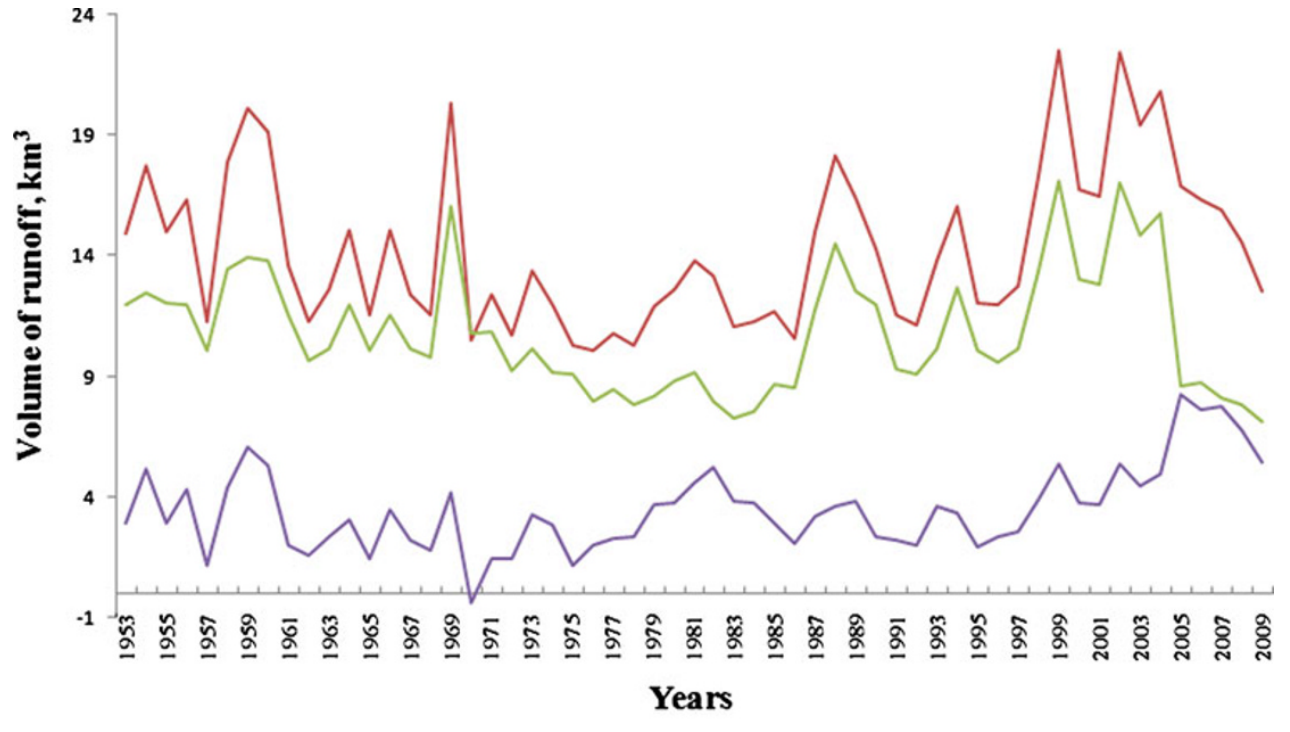

-Runoff at the peak of delta - Runoff coming into Lake Balkhash - Loss ofDelta reservoir Kapshagai, a portion of the accumulated water of the delta began to flow into Balkhash contributing to the excess of outflow relative to inflow.

Figure 3 shows the dynamics of the multi-flow Ile River delta from 1953 to 2009.

There is an increase in the heavily regulated water under the percentage of water loss to runoff entering the delta of Ile. This is mainly due to violation of the natural mode of distribution of water flow within the year. Elevated winter releases of water into the downstream reservoir Kapshagai has been undertaken to cover peak loads in the power of the region, causing a sharp rise in the levels in the Ile delta and extensive flooding of the territory. The water received during this period between channels in undrained depressions, lakes and flooding in the future is almost completely lost forever.

Within a heavily regulated environment in the 1970-2009 years, Lake Balkhash received an average of $330 \mathrm{~m}^{3} / \mathrm{s}$ or $10.4 \mathrm{~km}^{3} /$ year, and up-regulation of River Ile Kapshagai reservoir in 1953-1969 years received an average of $11.8 \mathrm{~km}^{3}$.

As it can be seen, 1988-2005 observed a slight increase in runoff losses in the Ile delta in the wet years with maximum values in the years $1988\left(18.1 \mathrm{~km}^{3}\right), 1999$ $\left(22.5 \mathrm{~km}^{3}\right)$ and $2002\left(22.4 \mathrm{~km}^{3}\right)$.

\section{Conclusion}

The result of the investigations a number of works the following results: collected and analysis of hydrological and mapping data on the hydrographic network of Ile River delta are revisions their contemporary settings. The current state of the river network of Ile River delta was also assessed.

Based on available materials, the hydrological regime of Ile River delta for a (regime of water flow at the peak of Ile River delta, flow distribution on individual sleeves, as well as natural water loss) multiyear period was studied. Following estimate of the current state regime hydrological characteristics of the Ile River delta.

The arrival of water runoff to the delta of the Ili River and also natural loss of water were calculated, with which it was possible to estimate the ecological minimum water flow needed to maintain the level of Lake Balkhash in stable condition. 
Open Access This article is distributed under the terms of the Creative Commons Attribution License which permits any use, distribution, and reproduction in any medium, provided the original author(s) and the source are credited.

\section{References}

Abdrasilov SA (1994) Fluvial processes and formation of intracontinental delta (for example, delta of the Ili River). Rauan, Almaty, pp 92-94

Dostay ZD (2009) Management of hydro-ecosystems basin of Lake Balkhash. Institute of Geography, Almaty, p 235

Geology of the USSR (1971) South Kazakhstan. Publisher of subsurface 40, Moscow, p 534

Kudrin RD (1977) The role delta of the Ili River and climatic factors at the Lake Balkhash level fluctuations. J Water Res, no. 1, Moscow. pp 143-150

Report of scientific research (1989) Develop recommendations and complex of measures to intensify use and protection recourses of the Lake basin Balkhash. Institute of Geography, Almaty, p 209

Report of scientific research (1990) Hydrological aspects of monitoring the delta of the Ili River. Almaty

Report of scientific research (1991) Geoecological monitoring and assessment of environmental quality Balkhash (delta of Ili River). Institute of Geography, Almaty, p 138

Report of scientific research (2010) Assess the modern and forecasting dynamics of hydrological regime of Lake Balkhash, Caspian and Aral seas. RGE "Kazhydromet", Almaty, p 187
Sosedov IS (1958) Loss of water for evaporation and transpiration in the delta of the Ili River. Publisher of the Kazakh SSR Academy of Sciences. Ser Energ 1(13):16-24

State Water Cadastre Republic of Kazakhstan (2001) Long-term data on the regime and resources of land surface water. RGE "Kazhydromet", vol 1, no. 4. Almaty

Surface water resources of Soviet Union $(1967,1980)$ The main hydrological characteristics, vol 13, no. 2. Gidrometeoizdat Press, St. Petersburg, p 645

Surface water resources of Soviet Union (1967) Hydrological study, vol 13, no. 2. Gidrometeoizdat Press, St. Petersburg, pp 7-210

Surface water resources of Soviet Union (1970) Central and southern Kazakhstan. Basin of Lake Balkhash, vol 13, no. 2. Gidrometeoizdat Press, St. Petersburg, pp 600-646

The hydrological yearbooks (1994-2009) RGE "Kazhydromet", vol 5, no. 5-8. Kazhydromet, Almaty, pp 440-447

Tursunov AA, Malkovsky IM, Abdrasilov SA (1985) Problems of rational use of water resources Lake Balkhash. Theses of scientific and practical conference dedicated to 50th anniversary Kazakh National University, Almaty, pp 55-78

Uvarov VN (1997) Contemporary relief-forming processes in the delta of the Ili River. Collection of scientific articles: contemporary relief-forming processes in Kazakhstan. Almaty, pp 70-73

Zhirkevich AN (1972) Water balance of Lake Balkhash and prospects of change associated with the use of water resources of the Ili-Balkhash Basin. Trudy KazNIGMI, 44. Almaty, pp 140-168 